\title{
Bankruptcy: The Disposition of the Debtor's Unliquidated Cause of Action for Personal Injuries
}

\begin{abstract}
Rand C. Schmidt*
This Comment examines the disposition of personal injury causes of action in bankruptcy courts in California. Defining and applying the "fresh start" doctrine expounded by the United States Supreme Court in such cases as Lines v. Frederick and Kokoszka v. Belford, the author suggests that the present practice in California, under which the entire cause of action normally passes to the trustee in bankruptcy, is erroneous. He proposes that personal injury causes of action should be broken into their component parts, with the "fresh start" doctrine applying to some components of the cause of action but not to others.
\end{abstract}

Section 70(a)(5) of the Bankruptcy Act provides that unliquidated causes of action for personal injuries do not pass to the trustee in bankruptcy unless they are "subject to attachment, execution, garnishment, sequestration, or other judicial process" under applicable state law. ${ }^{1}$ Most jurisdictions place personal injury causes of action beyond the reach of creditors. Under section 688.1 of the California Code of Civil Procedure, lowever, creditors may be granted liens against pending causes of action, ${ }^{2}$ including those for personal injuries. ${ }^{3}$

\section{Section 70 (a) provides in part:}

The trustee of the estate of a bankrupt and his successor or successors, if any, upon his or their appointment and qualification, shall in turn be vested by operation of law with the title of the bankrupt as. of the date of the filing of the petition initiating a proceeding under this title, except insofar as it is to property which is held to be exempt, to all of the following kinds of property wherever located .... (5) property, including rights of action which prior to the filing of the petition he could by any means have transferred or which might have been levied upon and sold under judicial process against him, or otherwise seized, impounded or sequestered. Provided, That rights of actions ex delicto for libel, slander, injuries to the person of the bankrupt or of a relative, whether or not resulting in death, seduction, and criminal conversation shall not vest in the trustee unless by the law of the State such rights of action are subject to attachment, execution, garnishment, sequestration, or other judicial process. . . .

Bankruptcy Act $\$ 70(a), 11$ U.S.C. $\$ 110$ (a) (1970).

2. Section 688.1 provides in part:

(a) Except as provided for in subdivision (b), upon motion of a judgment creditor of any party in an action or special proceeding made in the court 
Consequently, tort claims of bankrupt Californians pending when the petition in bankruptcy is filed pass to their trustees in bankruptcy under section 70(a)(5) of the Act. ${ }^{4}$

This result has not been seriously questioned in California since the enactment of section 688.1 in 1941. In Lines v. Frederick," however, the Supreme Court held that the scope of "property" passing to the trustee under section 70(a)(5) should be determined in accordance with the Act's underlying purposes; if allowing an asset to pass to the trustee defeats those purposes, that asset may be deemed not to be "property" within the meaning of section 70(a)(5). ${ }^{\circ}$ This Comment will review the status of unliquidated personal injury claims in bankruptcy proceedings in California and will consider the propriety

in which the action or proceeding is pending upon written notice to all parties, the court or judge thereof may, in his discretion, order that the judgment creditor be granted a lien upon the cause of action, and upon any judgment subsequently procured in such action or proceeding, and, during the pendency of such action, may permit such judgment creditor to intervene therein. Such judgment creditor shall have a lien to the extent of his judgment upon all moneys recovered by his judgment debtor in such action or proceeding and no compromise, settlement or satisfaction shall be entered into by or on behalf of such debtor without the consent of such judgment creditor, unless his lien is sooner satisfied or discharged.....

(b) Nothing in this section shall be construed to permit an assignee by operation of law of a party to a personal injury action to acquire any interest in or lien rights upon any moneys recovered by such party for general damages. CAL. Code CIV. Pro. \$ 688.1 (West Supp. 1974).

3. Apostolos v. Estrada, 163 Cal. App. 2d 8, 328 P.2d 805 (2d Dist. 1958).

4. E.g., Carmona v. Robinson, 336 F.2d 518 (9th Cir, 1964); In re Kanter, 345 F. Supp. 1151 (C.D. Cal. 1972); In re Calestini, 321 F. Supp. 1313 (N.D. Cal. 1971); In re Farris, 217 F. Supp. 598 (N.D. Cal. 1963). The bankrupt may avoid the consequences of this rule by commencing his personal injury suit after filing a petition in bankruptcy. Furthermore, the filing of the petition operates as an automatic stay against lien enforcement, Bankruptcy Rule 601, so that creditors will probably be precluded from obtaining liens under section 688.1 once the petition has been filed. Under section 4-503(c)(8) of the new Bankruptcy Act proposed by the Bankruptcy Laws Commission, "proceeds, benefits or other rights to which the debtor is entitled as a result of any personal injury. . ." would be exempt as a matter of federal law. BANkRUpTCY Laws Commission Report, H.R. Doc. No. 137, pt. 2, 93d Cong., 1st Sess. 125-26 (1974).

5. 400 U.S. 18 (1970) (per curiam).

6. Id. at 19-20. Lines resolved a conflict between the circuits regarding the status of vacation pay earned but unpaid at the time of bankruptcy, holding that such pay does not pass to the trustee. TVA v. Kinzer, 142 F.2d 833 (6th Cir. 1944), had held that unpaid vacation pay did not pass to the trustee because of its contingent nature, while Kolb v. Berlin, 356 F.2d 269 (5th Cir. 1966), In re Cohen, 276 F. Supp. 889 (N.D. Cal. 1967), and In re Kuether, 203 F. Supp. 223 (N.D. Cal. 1962), had reached a contrary conclusion. See Greenfield, Lines v. Frederick: The Effect of Bankruptcy on a Bankrupt's Accrued Vacation Pay and other Forms of Deferred Compensation, 47 L.A.B.J. 67 (1971); Lee, Title to Property-Bankrupt's Vacation Pay, 45 REF. J. 115 (1971); Coinment, Bankruptcy - Wage Earner's Vacation Pay Held Not to be Property Under Section 70(a)(5), 49 N. CAR. L. Rev. 738 (1971); Comment, Bankruptcy, Bankrupt Retains Accrued Vacation Pay, 73 W. VA. L. REV. 302 (1971). 
of allowing such claims to pass to the trustee in light of Lines and other decisions. $^{7}$

\section{I}

\section{THE BANKRUPTCY ACT AND ITs INTERPRETATION BY THE COURTS}

\section{A. The Bankruptcy Act Prior to 1938}

Prior to the Chandler Act amendments of 1938, it was "well settled" that the bankrupt's unliquidated personal injury cause of action did not vest in the trustee. ${ }^{8}$ As originally enacted, section 70(a)(5) of the Bankruptcy Act of 1898 provided:

[t] he trustee . . . shall . . be vested by operation of law with the title of the bankrupt, as of the date he was adjudged bankrupt . . . to all ... (5) property which prior to the filing of the petition he could by any means have transferred or which might have been levied upon and sold under judicial process against him; . . . (6) rights of action arising upon contracts or from the unlawful taking or detention of, or injury to, his property. ${ }^{9}$

No specific reference was made to unliquidated personal injury causes of action, but the Act was interpreted to preclude allowing such causes of action to pass to the trustee. ${ }^{10}$ In this respect the law apparently followed the Bankruptcy Act of 1867, regarding the right to sue for personal injuries as strictly personal and not properly subject to division by creditors. ${ }^{11}$ As one court expressed the matter, it was beyond the

7. This Comment will not consider the extent to which liens on the bankrupt's pending personal injury causes of action are voidable by the trustee under sections $67(\mathrm{a}), 70(\mathrm{c})(3)$, and $70(\mathrm{e})$ of the Bankruptcy Act, 11 U.S.C. $\$ \$ 107(\mathrm{a}), 110(\mathrm{c})(3)$, 110 (e) (1970). Parenthetically, however, it may be noted that the term "property" also appears in section $70(c)(3)$ and is arguably subject to the same construction under Lines v. Frederick as is "property" in section $70(\mathrm{a})(5)$. A determination that personal injury causes of action are not "property" within those sections would presumably permit the bankrupt to avoid liens obtained within four months of bankruptcy himself. See Chicago, B. \& Q. R.R. v. Hall, 229 U.S. 511 (1913).

8. Saper v. Delgado, 146 F.2d 714, 715 (2d Cir. 1945).

9. Act of July 1, 1898, ch. 541, 30 Stat. 565-66. The current Bankruptcy Act is the Act of July 1, 1898, as amended. See 1 H. Remington, Treatise on the BanzRUPTCY LAW OF THE UNited States 19 (5th ed. 1950).

10. As the Fourth Circuit explained:

Subsection 5 and subsection 6 of section 70 (a) ... must be read together and Congress evidently intended that rights of action should be dealt with in subsection 6, which provides that only rights of action arising upon contract or from unlawful taking or detention of or injury to the bankrupt's property shall pass to the trustee. Under the rule of construction of statutes, other rights of action are excluded and do not pass.

Ruebush v. Funk, 63 F.2d 170, 172 (4th Cir. 1933).

11. Board of Trade v. Weston, 243 F. 332, 335 (7th Cir. 1917); In re Haensell, 91 F. 355, 356 (N.D. Cal. 1899). 
purpose of the law "to coin into money for the profit of his creditors the bodily pain, mental anguish or outraged feeling of a bankrupt." ${ }^{22}$

\section{B. The Chandler Act Amendments of 1938}

In 1938, the Chandler Act amended section 70(a)(5) by adding a proviso that "rights of action ex delicto for . . . injuries to the person of the bankrupt... shall not vest in the trustee unless by the law of the State such rights of action are subject to attachment, execution, garnishment, sequestration, or other judicial process." 13 This modification had the effect of rendering a bankrupt's personal injury cause of action potentially subject to hquidation and distribution by the trustee for the first time, depending on applicable state law.

The new proviso, lowever, has had minimal effect, since the majority of jurisdictions exempt personal injury causes of action as a matter of state law. Courts have tended to apply the proviso in a mechanical fashion, determining first whether state law subjects personal injury causes of action to "attachment, execution, garnishment, sequestration, or other judicial process" and then upholding or denying the trustee's claim to the cause of action accordingly. ${ }^{14}$ These decisions lave devoted little discussion to policy considerations, perhaps because in most cases the result was already in accord with the court's conscience, while in the minority of jurisdictions not exempting personal injury causes of action, no escape from the clear language of the Act was thought possible. ${ }^{15}$

12. Sibley v. Nason, 196 Mass. 125, 130; 81 N.E. 887,889 (Sup. Jud. Ct. 1907).

13. 11 U.S.C. $\$ 110(a)$ (1970) (emphasis added). This was only one of numerous changes under the Chandler Act. See $1 \mathrm{H}$. Remington, Treatise on the BankRUPTCY LAW OF THE UNITED STATES 20-21 (5th ed. 1950).

14. Compare Carmona v. Robinson, 336 F.2d 518 (9th Cir. 1964); In re Kanter, 345 F. Supp. 1151 (C.D. Cal. 1972); In re Calestini, 321 F. Supp. 1313 (N.D. Cal. 1971 ) and In re Farris, 217 F. Supp. 598 (N.D. Cal. 1963) (holding title vests in the trustee) with In re Buda, 323 F.2d 748 (7th Cir. 1963); Saper v. Delgado, 146 F.2d 714 (2d Cir. 1945) and In re Anderson, 345 F. Supp. 840 (E.D. Tenn. 1972), aff'd 474 F.2d 1398 (6th Cir. 1973) (holding title does not vest in the trustee).

15. Section $70(a)(5)$ vests title to "property" in the trustee subject to the proviso that "rights of action ex delicto for ... injuries to the person . . . shall not vest in the trustee unless by the law of the State such rights of action are subject to . . . judicial process . . . ." Although Lines requires that the content of the generic term "property" be determined in light of the purposes of the Act, it could be argued that Congress intended to preclude a similar approach to personal injury rights of action by specifically mentioning them. Even if this unlikely conclusion were accepted, however, it does not necessarily follow that personal injury rights of action vest in the trustee whenever subject to a state's judicial process. Section $70(a)(5)$ inerely provides that such rights of action shall not vest unless subject to judicial process; it does not require that they so vest. Arguably this language means that the bankrupt may retain his personal injury causes of action in certain instances. To be consistent with Lines, the determination of when the bankrupt may do so should be controlled by the Act's purposes. Of course, the practical consequences of applying Lines in this connection rather than in the construction of the term "property" are the same. 


\section{California Precedent}

Prior to the Chandler Act, personal injury causes of action were nonassignable in California ${ }^{16}$ and therefore were beyond the reach of the trustee in bankruptcy. ${ }^{17}$ The Chandler Act did not work an immediate change in this situation, however, because until 1941 unliquidated claims for personal injuries were not subject to "attachment, execution, garnishment, sequestration, or other judicial process" in California. In that year, Code of Civil Procedure section $688.1^{18}$ was enacted, providing a method whereby a court could grant to a judgment creditor a hen upon the debtor's pending cause of action. The first reported case to consider the question, In re Farris, ${ }^{19}$ held that this discretionary lien procedure was "other judicial process" within the meaning of section 70(a)(5) and that title to a personal injury cause of action therefore passed to the trustee. The court's holding was largely conclusory and practically devoid of precedent. ${ }^{20}$ The critical issue of whether the legislature intended to change existing law by nnaking section 688.1 applicable to personal injury causes of action was not discussed. ${ }^{21}$ Despite these shortcomings, Farris was later viewed as "persuasive authority" and followed by the Ninth Circuit in Carmona $v$. Robinson. ${ }^{22}$

Two developments prompted the federal district court to reconsider the issue when it decided In re Kanter ${ }^{23}$ in 1972. The first of these was the addition of subsection (b) to Code of Civil Procedure section 688.1 in 1970 , providing that "[n]othing in this section shall be construed to permit an assignee by operation of law of a party to a personal injury action to acquire any interest in or lien rights upon any moneys recovered by such party for general damages."24 This

16. Everts v. Will S. Fawcett Co., 24 Cal. App. 2d 213, 215, 74 P.2d 815, 816 (4th Dist. 1937). See also Wikstrom v. Yolo Fliers Club, 206 Cal. 461, 274 P. 959 (1929); Rued v. Cooper, 109 Cal. 682, 34 P. 98 (1893).

17. In re Haensell, 91 F. 355 (N.D. Cal. 1899).

18. Cal. CODE Civ. Pro. $\S 688.1$ (West Supp. 1974), reproduced in part at note 2 supra.

19. 217 F. Supp. 598 (N.D. Cal. 1963). Two unreported decisions had previously held that the cause of action passed to the trustee. In re Kratoska, No. 116225-MC (S.D. Cal., Oct. 4, 1962); In re Carreira, No. 60141 (N.D. Cal., May 12, 1961).

20. The only judicial precedent cited by the court is the unreported decision In re Carreira, No. 60141 (N.D. Cal., May 12, 1961).

21. In the earlier decision of Apostolos v. Estrada, 163 Cal. App. 2d 8, 328 P.2d 805 (2d Dist. 1958), the parties and the court assumed without discussion that section 688.1 applied to personal injury causes of action. Nothing in section 688.1 itself, however, indicates a legislative intent to alter the contrary rule of prior law. See Note, Work of the 1941 California Legislature, 15 S. CAL. L. REv. 1, 18 (1941).

22. 336 F.2d 518, 520 (9th Cir. 1964).

23. 345 F. Supp. 1151 (C.D. Cal. 1972).

24. Cal. Code Crv. Pro. § 688.1(b) (West Supp. 1974). 
measure was specifically designed to counter the effects of Farris and Carmona. ${ }^{25}$ However, since it purported to affect only trustees in bankruptcy without imposing a corresponding restriction upon creditors generally, the court in Kanter declared subsection (b) unconstitutional under the supremacy clause. ${ }^{26}$

The second developinent which caused the court in Kanter to reconsider Carmona was the United States Supreme Court decision in Lines v. Frederick. ${ }^{27}$ In Kanter the court decided that Lines was not applicable and lield that the bankrupt's personal injury cause of action passed to the trustee, ${ }^{28}$ thereby reaffirming Carmona. To determine the propriety of this holding requires an examination of Lines and its predecessors.

\section{The Supreme Court's Decision in Lines v. Frederick}

In Lines v. Frederick, ${ }^{29}$ the Supreme Court considered the question of whether a bankrupt wage earner's vacation pay, accrued but un-

25. The legislative intent behind section 688.1(b) was revealed in a letter from its sponsor, Assemblyman Edwin L. Z'Berg, to bankruptcy Referee James E. Moriarty. That letter reads in part:

"I am not specifically familiar with the case of Carmona vs. Robinson, so I can't comment on it in detail. I assume that indirectly I was aware of the ruling in tbat case, if the ruling held that when a person is judicated to bankrupt that his interest in a personal injury case is an asset of the estate.

"It was precisely this state of the law which the legislation was introduced to effect [sic]....

"In my opinion the phrase... assignee by operation of law . . . includes only a Trustee in Bankruptcy. . . .

"[M]y purpose was to not have the general damages in a personal injury cause of action be an asset of the bankrupt estate, but rather have these exempt from the bankruptcy assets.

"[M] $[$ intention in the drafting of the bill was that only those items which are special damages in a personal injury law suit up to the time of the bankruptcy would be the things that could be shared in the proceeds of a personal injury action in the bankrupt estate.

"That would necessitate a request for special findings, of course, but those special findings could designate what part of the judgement [sic] was for special damages, i.e., medical bills, hospital bills, etc., prior to filing of the bankruptcy and what part of the judgment was for general damages. The general damages being then exempt and not a part of the bankruptcy estate."

Letter from Edwin L. Z'Berg to James E. Moriarty, Jan. 10, 1972, in In re Kanter, 345 F. Supp. 1151, 1154-55 (C.D. Cal. 1972).

26. 345 F. Supp. at 1156. As the court observed, the "Legislature could have amended C.C.P. $\$ 688.1$ to provide that no creditor could execute or place a lien upon the general damages of any pending Court action arising out of personal injuries" without violating the supremacy clause. Id. See D. Cowans, BankRuptcy Law and PracTICE $§ 591$ (1973 Cum. Supp.); Trost, Recent Developments in Debtor ProtectionLimitations on Creditors' Remedies and the New Exemption Laws, 46 CAL. ST. B.J. 639, 647 (1971). See also Perez v. Campbell, 402 U.S. 637 (1971).

27. 400 U.S. 18 (1970).

28. In re Kanter, 345 F. Supp. 1151, 1156-57 (C.D. Cal. 1972).

29. 400 U.S. 18 (1970). 
paid at the time of the filing of the petition in bankruptcy, passed to the trustee as "property" under section 70(a)(5) of the Act. The case actually involved two separate vacation plans. Under one plan, all einployees received a "vacation" with pay during an annual plant shutdown; the other, more conventional plan permitted employees to take vacations when they desired. Without differentiating between the two plans, the Court held that the accrued vacation pay was not "property" for section $70(a)(5)$ purposes and therefore did not pass to the trustee in bankruptcy. ${ }^{30}$

Prior to Lines, the disposition of such vacation pay had been determined by whether its ultimate receipt was too contingent to allow treating it as property ${ }^{31}$ and, if not, whether it was then transferable or leviable under state law. ${ }^{32}$ Lines substituted a new test, borrowed from the earlier decision in Segal $v$. Rochelle: ${ }^{33}$ a particular asset may be viewed as "property," title to which passes to the trustee under section 70(a)(5), if it is "sufficiently rooted in the pre-bankruptcy past and so little entangled with the bankrupt's ability to make an unencumbered fresh start that it should be" so regarded. ${ }^{34}$ Under this test, the relationship of the asset both to the bankrupt's past and his future must be considered in determining whether it is "property" for section 70(a)(5) purposes.

The concept of an asset being rooted in the pre-bankruptcy past is illustrated by Segal. In that case, the trustee claimed a tax loss carryback refund received by a partnership after its date of bankruptcy. The refund was generated by losses occurring prior to bankruptcy, however, which themselves may have precipitated the partnership's financial collapse. For this reason, the refund was held to be "sufficiently rooted in the pre-bankruptcy past" to justify treating it as "property" under section 70(a)(5). ${ }^{35}$ The Court may also have been concerned that the bankrupt would receive a windfall at the expense of creditors if the refund did not pass to the trustee. ${ }^{36}$

30. Id. at 20.

31. TVA v. Kinzer, 142 F.2d 833 (6th Cir. 1944). See also Fournier v. Rosenblum, 318 F.2d 525 (1st Cir. 1963); In re Sussman, 289 F.2d 76 (3d Cir. 1961).

32. Kolb v. Berlin, 356 F.2d 269 (5th Cir. 1966); Hill v. Schaefer, 221 F.2d 914 (5th Cir. 1955); Horton v. Moore, 110 F.2d 189 (6th Cir. 1940); In re Kuether, 203 F. Supp. 223 (N.D. Cal. 1962).

33. 382 U.S. 375 (1966).

34. Lines v. Frederick, 400 U.S. 18, 20 (1970).

35. 382 U.S. at 380.

36. In two prior circuit court cases it had been held that similar tax refunds did not pass to the trustee. Fournier v. Rosenblum, 318 F.2d 525 (1st Cir. 1963); In re Sussman, 289 F.2d 76 (3d Cir. 1961). In Segal, the Fifth Circuit characterized this result as a "windfall to the bankrupts at the expense of the creditors." Segal v. Rochelle, 336 F.2d 298, 300 (5th Cir. 1964), aff'd, 382 U.S. 375 (1966). 
The vacation pay in Lines was at least as well rooted in the prebankruptcy past as the tax refund in Segal. In each case, the right to receive the payment in question accrued before bankruptcy. The Court in Lines, however, nowhere questioned the sufficiency of the asset's connection with the past; rather, its decision rested on the other half of its dual test, the relationship of the asset to the debtor's postbankruptcy life. This part of the Court's test stems from one of the basic purposes of the Act: "to give the debtor a 'new opportunity in life and a clear field for future effort, unhampered by the pressure and discouragement of preexisting debt." "37 Under Lines, then, the significance of an asset to the debtor's "fresh start" may be determinative of whether that asset is "property" passing to the trustee. ${ }^{38}$ It is therefore important to explore the meaning of "fresh start" as used in Lines.

\section{E. Development of The Fresh Start Doctrine}

The "fresh start" doctrine appears to have originated in 1904 with the observation of the Supreme Court in Wetmore v. Markoe ${ }^{30}$ that "[s]ystems of bankruptcy are designed to relieve the honest debtor from the weight of indebtedness which has become oppressive and to permit him to have a fresh start in business and commercial life, freed from the obligation and responsibilities which may have resulted from busmess misfortunes." 40 The use of the word "business" twice in this statement is indicative of the judicial concern during this period that the bankrupt be restored to a productive role in society; ${ }^{41}$ his personal, financial and social welfare were apparently of secondary importance

37. 400 U.S. at 19.

38. Despite its reliance on the "fresh start" purpose of the Act, the Court in Lines made clear that the main purpose of 70 (a)(5) - "to secure for creditors everything of value the bankrupt may possess in alienable or leviable form . . ." - had not been abandoned. 400 U.S. at 19, quoting Segal v. Rochelle, 382 U.S. 375,379 (1966). The result is a balancing of interests between the creditors' right to all pre-bankruptcy property of the debtor (vindicated by the "rooted in the pre-bankruptcy past" test) and the debtor's right to a fresh start. Cf. Kokoszka v. Belford, 417 U.S. 642 (1974).

39. 196 U.S. 68 (1904). See Comment, Bankruptcy-Wage Earners Vacation Pay Held Not to be Property Under Section 7O(a)(5), 49 N. CAR. L. Rev. 738, 780 (1971).

40. Wetmore v. Markoe, 196 U.S. 68, 77 (1904) (emphasis added). Prior to Wetmore, the accepted statement of the purposes of the Act was found in $I n$ re Leslie, 119 F. 406 (N.D.N.Y. 1903): "The main purpose of the bankruptcy law is to prevent preferences, and secure a fair and equitable division of the bankrupt estate among the creditors, not to grant discharges. This end accomplished, the bankrupt is granted a discharge from all his debts." Id. at 410. Judge Ray, author of the Leslie opinion, was a member of the House Committee which considered the Bankruptcy Act of 1898. 1 H. REMINGTON, BANKRUPTCY 18 (1934).

41. "The general purposes of the 1898 Act were . . . (2) to give the honest bankrupt an opportunity to clear himself of debt burdens and make a new start in life to the end that he would again become a useful member of commercial society." Hunt, Changing Trends in Our Bankruptcy Legislation, 13 S. CAL. L. REv. 210, 221 (1940). 
to the courts. Although not explicitly stated, this early limitation on the meaning of fresh start is suggested by the cases. The contrast between Local Loan Co. v. Hunt ${ }^{42}$ and Legg v. St. John, ${ }^{43}$ decided by the Supreme Court within two years of each other, is illustrative.

Local Loan involved a debtor who assigned a portion of his unearned wages as security for a loan. ${ }^{44}$ He then filed a petition in bankruptcy and imcluded the loan in his schedule of liabilities. Following the discharge, the lender sought to enforce the previous assignment. The bankrupt brought suit in federal court in Illinois to enjoin enforcement. Although prior Illinois Supreme Court decisions had held that an assignment of future wages creates a hen which is not discharged in bankruptcy, ${ }^{4{ }^{\prime}}$ a unanimous Court held that this result was "precluded . . . by the clear and unmistakeable policy of the bankruptcy act ... 'to reheve the honest debtor from the weight of oppressive indebtedness and permit him to start afresh free from the obligation and responsibilities consequent upon business misfortunes." "46 The Court further observed:

When a person assigns future wages, he ... pledges his future earning power. The power of the individual to earn a living for himself . . . is in the nature of a personal hiberty quite as much as . . . it is a property right. To preserve its free exercise is of the utmost importance, not only because it is a fundamental private necessity, but because it is a matter of great public concern. . . . [T]here is little difference between not earning at all and earning wholly for a creditor. Pauperism may be the necessary result of either. ... The new opportunity in life and the clear field for future effort, which it is the purpose of the bankruptcy act to afford the emancipated debtor, would be of little value to the wage earner if he were obliged to face the necessity of devoting the whole or a considerable portion of his earnings .... to the payment of indebtedness incurred prior to bankruptcy. ${ }^{47}$

Twenty-one months after deciding Local Loan, the same court ${ }^{48}$ was called upon to review Legg v. St. John, ${ }^{49}$ a Sixth Circuit decision holding that the right to receive future disability payments under an insurance policy passed to the trustee in bankruptcy where the debtor's

42. 292 U.S. 234 (1934).

43. 296 U.S. 489 (1936).

44. 292 U.S. at 238.

45. Monarch Discount Co. v. Chesapeake \& Ohio Ry. Co., 285 IIl. 233, 120 N.E.

743 (1918); Mallin v. Wenham, 209 Ill. 252, 70 N.E. 564 (1904).

46. 292 U.S. at 244.

47. Id. at 245 .

48. It comprised Chief Justice Hughes and Associate Justices Van Devanter, McReynolds, Brandeis, Sutherland, Butler, Stone, Roberts, and Cardozo.

49. 76 F.2d 841 (6th Cir. 1935). 
right to receive the payments had matured prior to bankruptcy. Under the terms of his policy, Legg was entitled to receive payments only if the disability prevented him from engaging in gainful employment. Legg argued that the payments should be exempt as being in the nature of future earnings or after-acquired property. In rejecting this contention, the Court declared that the benefits were not "in any sense future earnings. They are not the fruit of anything done by Legg after the adjudication." 50 Accordingly, the Court ruled that the payments passed to the trustee as would any other right acquired before bankruptcy to receive money. ${ }^{51}$

Local Loan may be distinguished from Legg by the determination that Hunt, unlike Legg, had no right to receive his future wages prior to bankruptcy. This narrow and formalistic distinction, however, is hardly satisfying. In ruling for the trustee in Legg, the Court appears to have overlooked significant equitable considerations. The threat of indigence resulting from the deprivation of future income was, if anything, more real in Legg than in Local Loan; yet the Court remained unmoved. Perhaps the Court felt that the disability payments were not sufficiently important to the debtor's fresh start to require their exemption-but this would have been true only if "fresh start" were defined in terms of providing the bankrupt an incentive to play a productive role in society. Thus, aside from his physical disability, the withholding of Legg's disability benefits would not in itself have discouraged him from working to earn in the future. By contrast, Hunt would have had no incentive to work if his obligation to pay future wages to creditors were not discharged. On the other hand, if "fresh start" comprehended a minimal level of economic well-being for the debtor following bankruptcy, the two cases are more difficult to reconcile. Indeed, the disabled debtor in Legg was probably in more desperate circumstances after his bankruptcy than was Hunt.

\section{F. Application of the Fresh Start Doctrine to Financial Well-Being}

In Lines, the Court seems finally to have abandoned the notion that fresh start relates only to encouraging the debtor to resume a productive role in society. By observing that the function of the accrued vacation pay is to "support the basic requirements of life . . . during brief vacation periods" 52 and by expressing a concern for the "economic survival of the debtor," ${ }^{33}$ the Court indicated that fresh start should be viewed more broadly in terms of the debtor's financial well-

\footnotetext{
50. 296 U.S. at 492.

51. Id. at 495-96.

52. 400 U.S. at 20.

53. Id.
} 
being. This shift in perspective in favor of the debtor ${ }^{54}$ is confirmed by a comparison of Lines with Legg. In both cases, the right to receive the payments accrued prior to bankruptcy, and in neither case were the payments "the fruit of anything done" after bankruptcy. Furthermore, the vacation pay in Lines was no more necessary to a fresh start, defined in terms of the debtor's incentive to produce, than were the disability payments in Legg. In fact, depriving the wage earners in Lines of their vacation pay by requiring it to pass to their trustees would have increased the likelihood of their working to obtain an alternate source of income following bankruptcy. Despite these factual paralleis, the two cases reached opposite conclusions because the Court in Lines employed the fundamentally different notion that fresh start relates to the debtor's econonic well-being.

Unfortunately, "fresh" start is left undefined by the Lines Court. But the Court's citation of Sniadach v. Family Finance Co., ${ }^{55}$ a case involving the application of due process to wage garnishment, and its categorization of wages as a "special type of property," "w6 when coupled with its observation that the vacation pay had its source in wages, ${ }^{57}$ seems to indicate that Lines affords protection only to certain "wagebased" assets.

This argument was pressed in Kokoszka v. Belford, ${ }^{58}$ which involved the question of whether an income tax refund due to the excess withholding of taxes on pre-bankruptcy wages passed to the trustee in bankruptcy. The bankrupt argued that the refund was necessary for a "fresh start" because the funds withheld were derived solely from wages. ${ }^{59}$ In dismissing this argument, the Court distinguished Lines:

54. Certain cases in the years following Legg suggest favoring the bankrupt on close questions. See, e.g., Perez v. Campbell, 402 U.S. 637 (1971); Harris v. Zion's Savings Bank \& Trust Co., 317 U.S. 447, 451 (1943); Wright v. Union Central Ins. Co., 311 U.S. 273, 278-79 (1940). It should be noted that a bankruptcy court is essentially a court of equity. Pepper v. Litton, 308 U.S. 295, 304 (1939). See also Reading Co. v. Brown, 391 U.S. 471 (1968); Bank of Marin v. England, 385 U.S. 99 (1966). Equitable considerations have been seen as supplanting express statutory language in some areas of bankruptcy law, particularly section 70 (a)(5). See Aug, Recent Trends in the Application of Equitable Principles of Bankruptcy, 43 REF. J. 109 (1969); Comment, The Bankrupt's Right to Loss-Carryback Tax Refunds: Segal v. Rochelle, 50 MARQ. L. REV. 143, 149 (1966).

55. 395 U.S. 337 (1969), cited at 400 U.S. 18, 20 (1970). In Sniadach, a Wisconsin statute provided for pre-judgment garnishment of a wage earner's pay. The statute was held violative of due process because it failed to provide a hearing and notice to the debtor prior to seizure. The Court reasoned that the hardship imposed by garnishment procedures on wage earners with families to support required strict adherence to due process.

56. 400 U.S. at 20.

57. Id.

58. 417 U.S. 642 (1974).

59. Id. at 647 . 
Petitioner is correct in arguing that both his tax refund and the vacation pay in Lines share the common characteristic of being "waged based." It is also true, however, that only the vacation pay in Lines was designed to function as a wage-substitute at some future period .... This distinction is crucial. . . . [S]ince a "tax refund is not the . . . periodic income required by a wage earner for his basic support, to deprive him of it will not hinder his ability to make a fresh start . . . ."

The Court expressly rejected the idea that the wage-based character of an asset suffices to invoke the fresh start doctrine. Rather, it emphasized the need to analyze the precise nature of an asset in light of the dual purpose of the Act. ${ }^{81}$ The opinion, however, strongly suggests that where the asset is a wage substitute, the fresh start doctrine will apply to preclude the asset from passing to the trustee. ${ }^{62}$ With this modification, Kokoszka reaffirms Lines and indicates a willingness to view fresh start in the broad context of the debtor's economic wellbeing.

\section{II}

\section{The Application of the Fresh Start Doctrine TO PERSONAL INJURY ClaIMS}

In light of Lines and Kokoszka, what should be the proper disposition of an unliquidated tort claim? One court has suggested that the entire cause of action should be retained by the bankrupt. The decision in that case, In re Schmelzer, ${ }^{68}$ was reached after Lines but before Kokoszka; it involved questions similar to those presented in the Kanter case. $^{64}$ The federal district court in Schmelzer ${ }^{85}$ was imitially

60. Id. at 648 .

61. Id. at 645-46.

62. In light of the fact that both Lines and Kokoszka involved assets which were wage-based, it is at least arguable that an asset must be both wage-based and wageequivalent before the fresh start doctrine may be invoked. Although the issue is not free from doubt, a fairer reading of Kokoszka suggests that the Court there abandoned whatever reliance it had previously placed on the wage-based character of an asset and substituted instead a test looking only to the degree of wage-equivalency. It should be noted that requiring an asset to be both wage-based and wage-equivalent for the fresh start doctrine to apply is inconsistent with the rule that assets having sufficient roots in the pre-bankruptcy past pass to the trustee. This is because the wage-based character of an asset is itself a significant connection with the pre-bankruptcy past. Cf. Kokoszka v. Bolford, 417 U.S. 642 (1974); Lines v. Frederick, 400 U.S. 18 (1970). Such a view of the fresh start doctrine would produce the anomalous result that assets needed for the debtor's economic survival because of their wage-equivalency could be retained by him only to the extent of their connection with the pre-bankruptcy past.

63. 480 F.2d 1074 (6th Cir. 1973).

64. 345 F. Supp. 1151 (C.D. Cal. 1972), discussed in text accompanying notes 23-28 supra.

65. In re Schmelzer, 350 F. Supp. 429 (S.D. Ohio 1972), aff'd 480 F.2d 1074 (6th Cir. 1973). 
confronted with the question of whether Ohio law subjected unliquidated tort claims to judicial process as required by the proviso in section 70(a)(5). After reviewing the Ohio authorities, the court concluded that the disposition of such claims under Ohio law was unclear. ${ }^{86}$ It therefore considered itself free to proceed in accordance with the general policies underlying the Act. Noting the similarity between tort claims and the wage-related property afforded special protection in Sniadach and Lines, as well as the potentially serious consequences of withholding a recovery for serious personal injuries from an injured debtor, the court held that the bankrupt's right to a fresh start demanded that the cause of action not pass to the trustee..$^{67}$

On appeal, the Sixth Circuit affirmed, ${ }^{68}$ holding both that a claim for personal injuries is not "property" within section 70(a)(5) and that the trustee had failed to demonstrate that Ohio law met the requirements of that section. Although the holding could be read narrowly as resting solely on the question of state law, the court made clear its view that the purposes of the Act as outlined in Lines "can hardly be achieved if the trustee is permitted to take over the bankrupt's unliquidated claims for serious personal injuries including claims for future pain and suffering, continued disability, and loss of earnings in the future. It seems almost against public policy to permit the trustee in bankruptcy to prosecute such [an] action in his own name."

Despite their contradictory results both Schmelzer and Kanter suffer from a common defect. Neither case carefully analyzed the exact nature of a personal injury cause of action nor adequately considered the dual purposes underlying the law of bankruptcy. Whereas Kanter appears to have overlooked the fact that the ability of the bankrupt to make a fresh start following his discharge is to be protected, Schmelzer seems equally to have ignored the fact that bankruptcy is, after all, a process whereby a debtor's nonexeinpt property is liquidated and distributed for the benefit of his creditors.

Neither case sufficiently considered the fact that personal injury recoveries frequently consist of several distinct elements: recovery for loss of past and future earnings, recovery for past and future medical expenses, and recovery for pain and suffering. The requisite balancing of interests between the bankrupt and his creditors does not result in a similar disposition of each of these elements, for the relation-

66. For a further review of the Ohio cases, see Comment, Unliquidated Causes of Action for Personal Injury, 18 W. REs. L. REv. 1025 (1967).

67. $350 \mathrm{~F}$. Supp. at $436-38$.

68. In re Schmelzer, 480 F.2d 1074 (6th Cir. 1973).

69. Id. at 1077 . 
ship of each to the debtor's fresh start and the connection of each with the pre-bankruptcy past vary significantly.

\section{A. Compensation for Loss of Earnings}

That portion of the personal injury recovery representing reimbursement for loss of earnings prior to bankruptcy appears to have especially strong roots in the pre-bankruptcy past. Not only is this element of recovery a substitute for pre-bankruptcy wages, but, as in Segal, ${ }^{70}$ the loss of earnings may have helped precipitate bankruptcy. Subject to exemptions under state law, ${ }^{71}$ wages accrued but unpaid at the date of bankruptcy pass to the trustee, and there seems to be no compelling reason why a similar result should not follow where a substitute for such wages is involved. ${ }^{72}$ The importance of this type of asset to an unencumbered fresh start appears minimal, and both Lines and Kokoszka are limited to post-bankruptcy wage substitutes. Permitting a bankrupt to retain pre-bankruptcy wages, whether by virtue of local exemptions or otherwise, would effectively allow him a head start rather than a fresh start. ${ }^{73}$ Neither Lines nor Kokoszka compels such a result.

With regard to compensation for loss of post-bankruptcy earnings however, the opposite conclusion is mandated. First, the connection with the pre-bankruptcy past is far weaker. Even though the right to receive the earnings accrues prior to bankruptcy, loss of earnings could not, by hypothesis, aid in precipitating bankruptcy. More importantly, Lines and Kokoszka should be dispositive, since conpensation for postbankruptcy earnings is precisely the "equivalent of future wages"74 which those cases indicate should receive protection. This is so even if the award for loss of future earnings is payable in a lump sum rather than on a periodic basis. ${ }^{75}$ Furthernore, future earnings will generally be required to "support the basic requirements of life . . . ."78 Without them, the bankrupt is not only deprived of the opportunity for a fresh start, but is virtually assured of a bleak future. ${ }^{77}$

70. 382 U.S. 375 (1966).

71. 11 U.S.C. \& 24 (1970).

72. See In re Aveni, 458 F.2d 972 (6th Cir. 1972).

73. Cf. Segal v. Rochelle, 382 U.S. 375 (1966).

74. Kokoszka v. Belford, 417 U.S. 642,647 (1974).

75. Cf. id. at 648 .

76. Id.

77. One court has suggested that the opportunity for a fresh start entails being placed on the "same footing with others similarly situated." In re Aveni, 458 F.2d 972, 973 (6th Cir. 1972). It can be argued that a fresh start is denied when the portion of the recovery attribu'able to loss of future earnings passes to the trustee; in that situation, the bankrupt is not on the same footing with ba ak upts having no personal injury claims, for the latter at least retain the unimpaired abjity to earn a living. Nor is he 


\section{B. Compensation for Medical Expenses}

That portion of the recovery representing reimbursement for prebankruptcy medical expenses has particularly strong roots in the prebankruptcy period. As in Segal, the right to be compensated arises prior to bankruptcy. In addition, burdensome medical bills will likely play a major role in bringing about the debtor's financial collapse. Depriving the debtor of this element of his recovery should have only minimal impact on the opportunity for a fresh start since he will be fully compensated for his losses, at least in theory, by the remaining elements of the recovery. As compensation for past losses, the recovery for pre-bankruptcy medical expenses is not a substitute for anything in the debtor's post-bankruptcy life. If he retains this portion of the recovery while also receiving a discharge of the medical bills, the debtor enjoys a windfall-precisely the result sought to be prevented in Segal.

The situation with respect to conipensation for anticipated future medical expenses is different. Here, the only connection with the prebankruptcy period is that the right to receive such compensation accrues in that period. Clearly, these expenses could not give rise to the bankruptcy.

The critical question is whether the fresh start doctrine may be invoked. One factor arguing against application of the doctrine is the fact that a wage substitute is no longer involved. Neither Lines nor Kokoszka, however, suggests that this is an absolute requirement. Rather, Kokoszka indicates that the nature of the asset inust be analyzed in each case. ${ }^{78}$ While that opinion apparently requires that an asset furnish the "basic requirements of life" or "basic support,"79 it does not suggest that only wage substitutes can qualify. The issue no doubt turns on what is nieant by "basic requirements of life" and "basic support," but it is not unreasonable to conclude that medical attention to serious personal injuries is a "basic requirement of life." Indeed, it is not difficult to imagine situations in which life itself would depend on continued niedical care. Accordingly, the portion of the recovery attributable to post-bankruptcy medical expenses should be exempt under the fresh start doctrtine. Indeed, the basic purpose of the doctrine would be frustrated if this elentent of the recovery were to pass to the trustee, for then the debtor would be compelled to divert compensation for lost future earnings to pay nedical expenses. In this

similarly situated with other tort victims who may retain their recovery in compensation for their lost earnings.

78. 417 U.S. at $645-47$.

79. Id. at 648 . 
manner, that portion of the recovery to which the fresh start doctrine most clearly applies could not be used for such basic needs as food, lousing, and clothing. Finally, it seems inequitable to allow compensation for post-bankruptcy medical expenses to pass to the trustee, since these debts will not be discharged and the bankrupt's ability to pay them will be impaired by his physical condition. ${ }^{80}$

\section{Compensation for Pain and Suffering}

Although the pain and suffering incident to a personal injury do not themselves give rise to the bankruptcy, the right to receive compensation for them does accrue prior to bankruptcy. In the absence of countervailing considerations, this would be a sufficient connection with the pre-bankruptcy past to require the compensation to pass to the trustee. ${ }^{81}$

It is doubtful that significant countervailing considerations can be found. The portions of the recovery attributable to loss of post-bankruptcy earnings and medical expenses should theoretically assure the bankrupt's financial well-being, so that denying him compensation for pain and suffering would not impair his fresh start. In light of Kokoszka's emphatic statement that a basic purpose of the Act is to distribute all nonexempt property of the bankrupt to his creditors, it appears that the bankrupt must be content with his recoveries for loss of future earnings and future medical expenses. ${ }^{82}$

There are apparently no decisions in which the various elements of a personal injury recovery have been allocated between the bankrupt

80. A bankruptcy court is essentially a court of equity. See cases cited in note 54 supra.

81. Cf. Legg v. St. John, 296 U.S. 489 (1936).

82. Despite the probable inapplicability of the fresh start doctrine, there is still room for argnment based on the equitable nature of bankruptcy. See cases cited in note 54 supra. As one court asked: Should the debtor be required to coin his body into money for the benefit of his creditors? Ruebush v. Funk, 63 F.2d 170, 173 (4th Cir. 1933). To allow this involves an element of windfall to the creditors, for had bankruptcy occurred in a non-injury context, there would be no corresponding asset available to them. There is no reason why the debtor's misfortune should inure to the benefit of his creditors. Arguably the pain and suffering portion of the recovery should be exempt under the rule, recognized by some courts, that doubt on close questions is resolved in favor of the debtor. Wright v. Union Central Íns. Co., 311 U.S. 273, 278-79 (1940); In re Schmelzer, 350 F. Supp. 429, 436 (S.D. Ohio 1972), aff'd, 480 F.2d 1074 (6th Cir. 1973). Refusing to allow the pain and suffering portion of personal injury recoveries to pass to the trustee would also be consistent with their treatment in other areas of the law. The Internal Revenue Code, for example, excludes recoveries for personal injury from gross income. INT. REv. CODE of 1954, $\S 104 \mathrm{a}(2)$. The rationale for this result is that the recovery merely "inake[s] the taxpayer whole from a previous loss of personal rights-because, in effect, they restore a loss to capital." Starrels v. Commissioner, 304 F.2d 574, 576 (9th Cir. 1962). See also Harnett, Torts and Taxes, 27 N.Y.U.L. REV. 614 (1952); Note, Taxation of Damage Recoveries from Litigation, 40 CORNELL L.Q. 345 (1955). 
and the trustee. Nevertheless, there seems to be no compelling reason why this could not be done. A special verdict would probably be required in personal injury suits brought by bankrupt plaintiffs, but these cases are likely to be so few in number as to pose no problems in terms of judicial administration. ${ }^{83}$ Moreover, there is sone authority for the division of a single asset into "property" and "non-property" coinponents for purposes of section 70(a)(5). In re Cedor, ${ }^{84}$ for example, involved a tax refund which was held not to be "property" within section $70(a)(5)$ except to the extent attributable to withholding in excess of statutory requirements. ${ }^{85}$

\section{CONCLUSION}

By failing to analyze carefully the various elements of the debtor's personal injury recovery, bankruptcy courts in Californa have reached a result, exemplified by In re Kanter, which subserves only one of the Bankruptcy Act's two principle purposes. While Lines and Kokoszka hardly deinand that the entire recovery be reserved to the bankrupt, they do require that those portions of the recovery important to the bankrupt's ability to make a fresh start-compensation for loss of future earnings and future medical expenses-be withheld froin the trustee.

83. In an Ohio State University Study, three percent of the bankrupts studied had suffered a loss of incoine due to personal injury which was thought to be a cause of the bankruptcy. H. Mathews, Causes of Personal BankRuptcies 53, 60 (1969). Of this group, the income reduction was found to be the critical factor in only three out of five cases. Id. at 60,62. See also R. Dolphin, AN ANALYsis of Economic AND Personal Factors Leading to Consumer Bankruptcy 85-87 (1965). Even these percentages are misleading, for not all personal injury causes of action of bankrupt tort victins are subject to section 70 (a)(5) in California. Only where the tort action is filed prior to the bankruptcy petition can the cause of action vest in the trustee, since section 688.1 applies only if the personal injury suit is pending. See Treister, The Bankrupt's Cause of Action for Personal Injury, 40 L.A.B. BuLl. 37, 39 (1964).

84. 337 F. Supp. 1103 (N.D. Cal.), aff'd sub nom. In re Jaines, 470 F.2d 996 (9th Cir. 1972), cert. denied, 411 U.S. 973 (1973). See also Gehrig v. Shreves, 491 F.2d 668 (8th Cir. 1974). But cf. Kokoszka v. Belford, 417 U.S. 642 (1974) (implicitly overruling Cedor on other gounds).

85. 337 F. Supp. at 1105-07. 
